IRA-International Journal of Management \& Social Sciences

ISSN 2455-2267; Vol.06, Issue 01 (2017)

Pg. no. 67-84

Institute of Research Advances

http://research-advances.org/index.php/RAJMSS

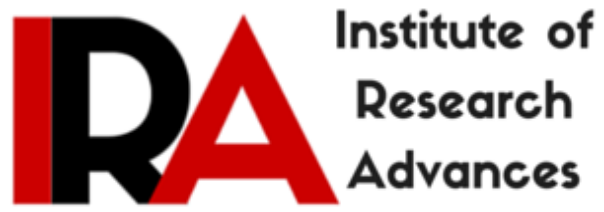

\title{
Abject Poverty and Multiple Deprivations in Rural India Based on SECC 2011 in Comparison with NSSO and NFHS: Summary Findings Analyzed
}

Joseph Abraham

Former Social Scientist, SECC Unit,

Ministry of Rural Development, New Delhi, India.

Type of Review: Peer Reviewed.

DOI: http://dx.doi.org/10.21013/jmss.v6.n1.p10

\section{How to cite this paper:}

Abraham, J. (2017). Abject Poverty and Multiple Deprivations in Rural India Based on SECC 2011 in Comparison with NSSO and NFHS: Summary Findings Analyzed. IRAInternational Journal of Management \& Social Sciences (ISSN 2455-2267), 6(1), 67-84. doi:http://dx.doi.org/10.21013/jmss.v6.n1.p10

(C) Institute of Research Advances

(cc) EY-NC

This work is licensed under a Creative Commons Attribution-Non Commercial 4.0 International License subject to proper citation to the publication source of the work.

Disclaimer: The scholarly papers as reviewed and published by the Institute of Research Advances (IRA) are the views and opinions of their respective authors and are not the views or opinions of the IRA. The IRA disclaims of any harm or loss caused due to the published content to any party. 


\section{Introduction}

This paper analyzes latest findings from the recently completed Socio Economic and Caste Census 2011(SECC2011), by focusing on rural abject poverty and multi-dimensionality of it by the pre-set seven deprivation parameters across rural India .As per schema of SECC2011 for analyzing the various facets of multi-dimensional poverty, firstly one set of households will be excluded on the basis of 13 automatic exclusion parameters, and subsequently another set of households will be automatically included on the basis of five parameters and finally the remaining set would be subjected to verifications by seven deprivations. Thereby, the SECC 2011 had set in motion an effort to capture some specifics of multidimensional poverty as desired by the Ministry of Rural Development (MoRD) in the Government of India. It is surmised here that the union of automatically included and deprived households will provide a base line of the number of poor through a multi-dimensional mode. The intersection of automatically included households with the seven deprivations variables will also identify the socio economic characteristics of the abjectly poor. Besides presenting the above analysis of SECC data, an attempt is made to compare these findings with those based on the unidimensional National Sample Survey (NSSO) poverty ratios ( by S.Tendulker 2009, C Rangarajan 2012) and multi-dimensional (R. Radhakrishna et al 2010) NFHS data based studies. A separate set of multi-dimensional poverty numbers were arrived at in the past for three Five Year Plans (1992-97, 1997- 02, 2002-07) through the Below Poverty Line (BPL) Censuses that were under taken by the Ministry of Rural Development (MoRD) to identify the poor households through the State/UT Governments. These later estimates of poor households were never permitted to exceed the official poverty ratio worked out by the Planning Commission for respective State/UT governments. The concepts used to arrive at these poor households will be briefly reviewed here as a prelude to explaining the modes operandi of identifying multi dimensional poverty via SECC 2011. A committee was set in up in February 2013 under the Chairmanship of Abhijit Sen, then Planning Commission Member, to examine the SECC indicators for data analysis, to recommend appropriate methodologies for determining classes of beneficiaries for different rural development programmes. Some of the recommendations of the committee would also be put to scrutiny.

\section{Unidimensional Poverty}

In the past, measurement of poverty was largely been dealing with economic deprivation in terms of income or in the expenditure space. The official estimates of poverty since the mid 1970s have been based on nationwide household consumer expenditure surveys conducted by the NSSO quinquennially adopting more or less common methods and procedures. The unidimensional or income poverty builds on the proposition that the living standard of a household depends on the commodities it consumes. This in turn depends on the level of consumption expenditure and the prices paid by the households for those items. The basic step in the income poverty approach is to identify a critical value of expenditure that can serve as a poverty line. Recently, C. Rangarajan Expert Group (set up in 2012) worked out the average requirements of calories, proteins and fats based on ICMR norms differentiated by age, gender and activity for all India. The energy requirements work out to $2155 \mathrm{kcal}$ per person in rural and 2090kcal in urban areas of the country. Based on this norm the poverty line works out to an average monthly per capita consumption expenditure of Rs 972 and Rs1407 respectively for rural and urban areas of the country at prices in 2011-12. This works out to Rs 32 and Rs 47 per person per day respectively in rural and urban areas. And arrived at the per centage of poor persons at 30.9 and 26.4 in rural and urban areas and $29.8 \%$ at all India level. As per C Rangarajan's report (2014) for those persons spending over Rs 32 and Rs 47 per day in rural and urban areas respectively are not to be counted as poor. This implied a monthly consumption expenditure of Rs 4860 in rural areas and Rs 7035 in urban areas for a family of five at 2011-12 prices, based on $68^{\text {th }}$ Round NSSO data for year 2011-12.The Planning Commission's estimates had drawn critical attention in September 2011 when in an affidavit to the Supreme Court it was stated by Government of India that households with per capita per day consumption of more than Rs 32 in 
urban areas and Rs 26 in rural will not be treated as poor,(based on S. Tendulkar Report 2009). The poverty ratio in the country declined to 21.9 per cent in 2011-12 from 37.2 per cent in 2004-05 on account of increase in per capita consumption (as per S. Tendulkar Committee set up in 2005). In 2011-12, the national poverty line, arrived at by using the Tendulkar methodology, estimated at expenditure Rs 816 per capita per month in villages and Rs 1,000 per capita per month in cities and arrived at 25.7, 13.7 and 21.9 per centages of poor persons respectively in rural, urban and at all India level by the Planning Com. In the unidimensional poverty domain based on NSSO data broadly three strands of poverty ratios are available for the country depending on the methodologies developed and used by three eminent economists namely Lakdawala, Tendulkar and Rangarajan. These poverty ratios and corresponding numbers of poor persons from 1973-74 till 2011-12 are given in below (Table.1).

\section{Multidimensional Poverty}

Corresponding to each of the three prior five year plans (FYPs 1992-97, 1997-02 and 2002-07) detailed procedure was prescribed by the Ministry of Rural Development to identify the BPL families in the rural areas. The 1992 survey used income as criterion, and guidelines were issued to assess the annual income of the family; the annual income cut-off was Rs 11,000 per household below which all were treated as poor. The BPL families were classified into income ranges of Rs 0-4,000, Rs 4,000-6,000, Rs 6,000-8,500 and Rs 8,500-11,000. The identified number of poor families through the lens of this survey far exceeded the poverty ratio estimated by the Planning Commission. The number of poor identified in the BPL survey was almost twice of that estimated number by the Planning Commission. Therefore, the procedures to conduct the BPL Census of 1997-02, was changed in substantial measure from that employed in 1992 in three major ways. Firstly, the criterion for determining the cut-off point was changed from income to consumption. Secondly, the concept of poverty line used in the census was changed from the household to person. Thirdly, before administering the questionnaire to figure out the level of consumption of the household, a set of exclusion criteria were applied to summarily eliminate the ineligible families so that adequate time and space could be ensured so as to precisely estimate the level of consumption of the potentially poor families. This methodology was criticised mainly due to the application of the exclusion criteria. For example, possession of a ceiling (electric) fan would categorise a family as non-poor. In other words, this has made such family ineligible for many BPL benefits. It must, however, be stated that except for using the criteria of electrical fan and two hectares (ha) of land (which could be quite unproductive in a few regions of India) for exclusion, the other parameters for exclusion were sound. The criticism was mainly articulated by the rich and powerful rural lobby because the exclusion criteria made it difficult for them to enter the list.

For the BPL Census of the Tenth FY Plan (2002-07), thirteen socio-economic indicators including size of land holding, type of house, availability of clothes, food security, sanitation, literacy, means of livelihood and indebtedness, reflecting the quality of life of the rural population, were identified to get an idea about the levels of living of the families. Here in also, the cut-off for the BPL category was determined by the percentages given by the Planning Commission's estimates for poor in the respective States. In other words, there could only be as many poor as the Planning Commission had estimated. Naturally, the cut-off for determining those who would be identified as poor were going to be different in each State. These criteria have been widely and bitterly criticised and attacked by rural poor people and their organizations, scholars, and the NGOs on a number of grounds. Firstly, a number of indicators in the score based methodology such as provision of toilets in the rural houses, housing, and education status of the children of the rural families, are likely to act as disincentives to the rural families from accessing these benefits for the fear of being excluded from the BPL list. Secondly, as no Panchayat-wise quota was fixed and most Panchayats recommended a large number of names and many of them were deleted at higher levels and also substituted the names of those who had political or bureaucratic clout. Panchayats/Gram Sabhas had power to recommend but did not have the authority for final decision making. (Now a days, the Grama Panchayats' are empowered with $73^{\text {rd }}$ Constitution amendment). 


\section{NFHS-Nutrition Based Poverty}

In the meanwhile, there has been a growing recognition that poverty is not simply a matter of inadequate consumption expenditures but also a matter of low literacy, short life expectation and lack of basic needs such as adequate shelter, clothing, better nutrition, health and safe drinking water etc. One stream of Multidimensional Poverty analyses have been worked out by pooling two different sets of unit level data viz., the National Sample Survey's 61st round (July 2004- to June 2005) consumer expenditure data and National Family Health Survey's (NFHS-3 in 2005-06) unit level data based on the methodology provided in Radhakrishna et al (2010). Such pooling of data has enabled them to estimate per capita total consumer expenditure for each NFHS sample households. The percentage of households either poor or with at least a stunted child (union of income poverty and child malnutrition) is estimated to be 72.6 per cent in rural and 60.9 per cent in urban areas. These figures show that the incidence of such multidimensional poverty is much higher than unidimensional ones. The percentage of households either poor or had a stunted child or women suffering from chronic energy deficiency are still higher at 82.6 percent in rural and 71.6 in urban areas. Thus, according to Radhakrishna et al (2010), in the unidimensional income space about $40 \%$ of the households are income poor, while in the multidimensional space, nearly three-fourths of the households suffer from poverty.

\section{Socio Economic and Caste Census 2011}

For Eleventh FY Plan (2007-2012) no BPL Census was conducted for various reasons. A court case in the Supreme Court came up from Civil Society. An Expert Committee headed by Dr.N.C. Saxena was set up in August 2008 as per directions of Supreme Court. The Committee submitted its report in August 2009. As per recommendation of the Committee a Pilot Study was taken up in 254 Villages across 22 States of the country. After incorporating the findings and recommendations of this pilot study, in June 2011 the SECC was started and completed by July 2015.

\section{Automatic Exclusion/Inclusion and Seven Deprivations in SECC}

In SECC ranking of households on the basis of information collected is attempted and no poverty line concept is followed. Poverty is multi-dimensional in nature and information collected from households form as a basis for prioritising to qualify for assistance under various programmes. In SECC 2011 all the rural households are grouped into three categories; (i). Automatically Excluded based on 13 parameters, (ii). Automatically Included based on five parameters; and (iii).Seven deprivation parameter qualifying households.

Table 1: NSSO Based Poverty Estimates from 1993-94 to 2011-12

\begin{tabular}{|c|c|c|c|c|c|c|}
\hline \multirow[t]{2}{*}{ Year } & \multicolumn{3}{|c|}{ Poverty Ratio (\%) } & \multicolumn{3}{|c|}{ Number of Poor(Million) } \\
\hline & Rural & Urban & Total & Rural & Urban & Total \\
\hline \multicolumn{7}{|c|}{ 1.Lakdawala Methodology } \\
\hline $1973-74$ & 56.4 & 49.0 & 54.9 & 261.3 & 60.0 & 321.3 \\
\hline $1977-78$ & 53.1 & 45.2 & 51.3 & 264.3 & 64.6 & 328.9 \\
\hline $1983-84$ & 45.7 & 40.8 & 44.5 & 252.0 & 70.9 & 322.9 \\
\hline $1987-88$ & 39.1 & 38.2 & 38.9 & 231.9 & 75.2 & 307.1 \\
\hline 1993-94 & 37.3 & 32.4 & 36.0 & 244.0 & 76.3 & 320.3 \\
\hline $2004-05$ & 28.3 & 25.7 & 27.5 & 220.9 & 80.8 & 301.7 \\
\hline \multicolumn{7}{|c|}{ 2. S. Tendulkar Methodology } \\
\hline $1993-94$ & 50.1 & 31.8 & 45.3 & 328.6 & 74.5 & 403.7 \\
\hline $2004-05$ & 41.8 & 25.7 & 37.2 & 326.3 & 80.8 & 407.1 \\
\hline
\end{tabular}


IRA-International Journal of Management \& Social Sciences

\begin{tabular}{|l|l|l|l|l|l|l|}
\hline $2009-10$ & 33.8 & 20.9 & 29.8 & 278.2 & 76.5 & 354.7 \\
\hline $2011-12$ & 25.7 & 13.7 & 21.9 & 216.7 & 53.1 & 269.8 \\
\hline 3.C. Rangarajan Methodology \\
\hline $2009-10$ & 39.6 & 35.1 & 38.2 & 325.9 & 128.7 & 454.6 \\
\hline $2010-11$ & 30.9 & 26.4 & 29.5 & 260.5 & 102.5 & 363.0 \\
\hline
\end{tabular}

Source: See Planning Commission GoI.2014

The SECC has covered a total 24.48 Crore households, both rural and urban, of these rural households are 17.97 Crores. Total households excluded all India (Rural) are 07.06 Crore \{(39.37\%) (i.e. households with at least one exclusion $\}$. A total of households Automatically Included are 0.16 Crore $\{(0.92 \%)$ (i. e. households with at least one inclusion, see Table.2)\} and total households deprived are 08.70 Crores $\{(48.51 \%)$, (households with at least one deprivation see Table.3). The households not reporting any deprivations are 2.01 Crores $(11.20 \%)$ and thereby total Multidimensionaly Poor households are 8.87Croes (49.43\%) (See, Table4, Col-2), at the base line. As defined the upper end number of poverty ridden households will be those with all automatically included plus all the seven deprivations qualified ones queuing up.

Table 2: Automatically Included Households

\begin{tabular}{|c|c|c|c|c|c|c|c|}
\hline States/ UTs Name & $\begin{array}{l}\text { Total } \\
\text { Households }\end{array}$ & $\begin{array}{l}\text { Total } \\
\text { Households } \\
\text { considered } \\
\text { for } \\
\text { Inclusion } \\
\end{array}$ & $\begin{array}{l}\text { HHs without } \\
\text { shelter }\end{array}$ & $\begin{array}{l}\text { HHs with } \\
\text { Destitute/ } \\
\text { living on } \\
\text { alms }\end{array}$ & $\begin{array}{c}\text { HHs with } \\
\text { Manual } \\
\text { scavengers }\end{array}$ & $\begin{array}{c}\text { HHs with } \\
\text { Primitive } \\
\text { tribal groups }\end{array}$ & $\begin{array}{l}\text { HHs with } \\
\text { Legally } \\
\text { released } \\
\text { bonded } \\
\text { labourers }\end{array}$ \\
\hline ALL India & 179620372 & 108909890 & $\begin{array}{r}134206 \\
(0.07)\end{array}$ & $\begin{array}{r}549235 \\
(0.31)\end{array}$ & $\begin{array}{l}89957 \\
(0.05)\end{array}$ & $845490(0.47)$ & $113241(0.06)$ \\
\hline A \& N ISLAND & 68481 & 29127 & $7(0.01)$ & $22(0.03)$ & $32(0.05)$ & $77(0.11)$ & $48(0.07)$ \\
\hline ARUNACHAL P & 201510 & 82777 & $3(0)$ & $94(0.05)$ & $273(0.14)$ & $3184(1.58)$ & $429(0.21)$ \\
\hline ASSAM & 5743835 & 4054697 & $1656(0.03)$ & $31873(0.55)$ & $0(0)$ & $0(0)$ & $0(0)$ \\
\hline BIHAR & 17829066 & 13036065 & $4004(0.02)$ & $25274(0.14)$ & $2126(0.01)$ & $3566(0.02)$ & $4807(0.03)$ \\
\hline CHANDIGARH & 15657 & 6407 & $1(0.01)$ & $9(0.06)$ & $0(0)$ & $0(0)$ & $0(0)$ \\
\hline $\begin{array}{l}\text { CHHATTISGAR } \\
\mathrm{H}\end{array}$ & 4539617 & 3720585 & $7083(0.16)$ & $23893(0.53)$ & $166(0)$ & $81562(1.8)$ & $586(0.01)$ \\
\hline GOA & 220731 & 35721 & $31(0.01)$ & $104(0.05)$ & $0(0)$ & $0(0)$ & $0(0)$ \\
\hline GUJARAT & 6920473 & 3684280 & $4707(0.07)$ & $16320(0.24)$ & $2(0)$ & $10447(0.15)$ & $0(0)$ \\
\hline HARYANA & 2969509 & 1189555 & $1896(0.06)$ & $4576(0.15)$ & $26(0)$ & $9(0)$ & $60(0)$ \\
\hline HIMACHAL P & 1263500 & 422715 & $667(0.05)$ & $1264(0.1)$ & $2(0)$ & $1(0)$ & $0(0)$ \\
\hline $\mathrm{J} \& \mathrm{k}$ & 1601606 & 839731 & $2168(0.14)$ & $4590(0.29)$ & $1368(0.09)$ & $3912(0.24)$ & $2770(0.17)$ \\
\hline JHARKHAND & 5044234 & 3477423 & $758(0.02)$ & $10097(0.2)$ & $1265(0.03)$ & $39253(0.78)$ & $1698(0.03)$ \\
\hline KARNATAKA & 8048664 & 4025962 & $3713(0.05)$ & $5359(0.07)$ & $4837(0.06)$ & $11242(0.14)$ & $6770(0.08)$ \\
\hline KERALA & 6319215 & 1930758 & $1273(0.02)$ & $9185(0.15)$ & $24(0)$ & $3905(0.06)$ & $22(0)$ \\
\hline LAKSHADWEEP & 10929 & 1519 & $0(0)$ & $6(0.05)$ & $0(0)$ & $5(0.05)$ & $2(0.02)$ \\
\hline
\end{tabular}


IRA-International Journal of Management \& Social Sciences

\begin{tabular}{|c|c|c|c|c|c|c|c|}
\hline MEGHALAYA & 485897 & 334186 & $123(0.03)$ & $703(0.14)$ & $83(0.02)$ & $210(0.04)$ & $243(0.05)$ \\
\hline NAGALAND & 284310 & 186987 & $26(0.01)$ & $475(0.17)$ & $108(0.04)$ & $314(0.11)$ & $189(0.07)$ \\
\hline NCT OF DELHI & 1051097 & 169430 & $482(0.05)$ & $691(0.07)$ & $0(0)$ & $0(0)$ & $17(0)$ \\
\hline ODISHA & 8622572 & 7000612 & $5204(0.06)$ & $49268(0.57)$ & $355(0)$ & $58773(0.68)$ & $5405(0.06)$ \\
\hline PUNJAB & 3269467 & 830900 & $1092(0.03)$ & $2638(0.08)$ & $1200(0.04)$ & $828(0.03)$ & $2950(0.09)$ \\
\hline RAJASTHAN & 10223073 & 6153074 & $12976(0.13)$ & $41721(0.41)$ & $1873(0.02)$ & $15999(0.16)$ & $1266(0.01)$ \\
\hline SIKKIM & 88723 & 49281 & $120(0.14)$ & $29(0.03)$ & $27(0.03)$ & $64(0.07)$ & $27(0.03)$ \\
\hline TAMILNADU & 10088119 & 5430138 & $2381(0.02)$ & $1974(0.02)$ & $70(0)$ & $33761(0.33)$ & $606(0.01)$ \\
\hline $\begin{array}{l}\text { UTTARAKHAN } \\
\text { D }\end{array}$ & 1479742 & 656412 & $981(0.07)$ & 1307 (0.09) & $141(0.01)$ & $2226(0.15)$ & $201(0.01)$ \\
\hline WEST BENGAL & 15756750 & 12454269 & $3967(0.03)$ & $\begin{array}{r}188228 \\
(1.19)\end{array}$ & $906(0.01)$ & $10605(0.07)$ & $986(0.01)$ \\
\hline
\end{tabular}

(Figures in parenthesis are per centages)

The distribution of deprived (D1 to D7) households indicates that the largest segment of such are from among the landless households deriving a major part of their incomes from manual casual labour (D7) followed by households with no literate adult above 25 years, then by SC/S households, then by D1 those with only one room, kucha walls and kucha roof etc.

\section{Two Stage Exclusion Method by Abhijit Sen Expert Committee}

The Abhijit Sen Committee recommended a two-stage method for exclusion of households as against the 13 parameter norm of SECC :- Stage 1 exclusion is applied to all households and those attracting any one of the four following criteria are excluded:- (i).Households having Motorized 4 wheelers; (ii).Household with any member as government employee; (iii).Household with any member Paying Income Tax Or Paying Professional Tax; (iv).Households having four or more rooms with all rooms having pucca walls and roof. Then in Stage 2, households which are not excluded as per the above criteria are brought in and households attracting any two of the following criteria are excluded :- (i).Household having Motorized 2/3 wheelers/fishing boat; (ii).Mechanized 3/4 wheeler agricultural equipment; (iii).Kisan Credit Card - credit limit Rs. 50,000 and above; (iv).Households with non-agricultural enterprises registered with Government; (v).Any member of HH earning more than Rs. 10000 per month; (vi).Three or more rooms with all rooms having pucca walls and roof; (vii).Owning a refrigerator; (viii).Owning a landline phone; (ix).Owning 2.5 acres or more of irrigated land with at least one irrigation equipment; (x).Owning 5 acres or more of irrigated land for two or more crop seasons; (xi).Owning at least 7.5 acres of land or more with at least one irrigation equipment. (See Table.4 for comparable results).Firstly, the Sen's above approach of not keeping out those households having three or more room houses with pucca walls and roofs from the exclusion club can be considered as adapting less stringent criteria, as the field realities are suggestive that those owning two/three pucca room and roofed houses may not be poor. Secondly, the reasoning to go in for two stage exclusion sorting and in the second stage to fix a households entry if qualified by any of the remaining two parameters are left unexplained besides being begin. 


\section{Modified Approach to Exclusion}

Contrary to the Expert Committee of SECC ( by Abhijit Sen) identified two-stage method for exclusion, the Economic Adviser MoRD has suggested a Modified Exclusion criteria and applied it to all households :- (i).E1.Household owning Motorized 4 wheelers; (ii).E2.Household with any member as government employee; (iii).E3. Household with any member Paying Income Tax / Professional Tax; (iv). E4.Households with two/three/four or more rooms with pucca walls and pucca roof; (v).E5.Households with any member earning more than Rs.10, 000 per month; (vi).E6. Households owning 5 acres or more land irrigated for two or more crop seasons; (vii). E7. Households owning 7.5 acres or more land with at least one irrigation equipment. (see Table. 4 for results).The Economic Adviser MoRD considered, realistically and robust enough, to exclude only all those households owning 4 wheelers from the

Table 3: Number of HHs with At-least One Automatic Inclusion and One Deprivation.

\begin{tabular}{|c|c|c|c|c|}
\hline States/ UTs Name & $\begin{array}{c}\text { Total } \\
\text { Households } \\
\end{array}$ & $\begin{array}{l}\text { HHs with any one } \\
\text { inclusion criteria }\end{array}$ & $\begin{array}{c}\text { HHs with At Least D } 1 \\
\text { Criteria }\end{array}$ & $\begin{array}{c}\text { At least I A1 + } \\
\text { At Least D 1 } \\
\end{array}$ \\
\hline ALL INDIA & 179620372 & $1655494(0.92)$ & $87140117(48.51)$ & $88795611(49.44)$ \\
\hline CHHATTISGARH & 4539617 & $112285(2.47)$ & $3178464(70.02)$ & $3290749(72.49)$ \\
\hline MEGHALAYA & 485897 & $1224(0.25)$ & $327506(67.4)$ & $328730(67.65)$ \\
\hline ODISHA & 8622572 & $117891(1.37)$ & $5692729(66.02)$ & $5810620(67.39)$ \\
\hline WEST BENGAL & 15756750 & $203209(1.29)$ & $10056266(63.82)$ & $10259475(65.11)$ \\
\hline NAGALAND & 284310 & $969(0.34)$ & $182441 \quad(64.17)$ & $183410(64.51)$ \\
\hline MADHYA PRADESH & 11288946 & $396787(3.51)$ & $6748026(59.78)$ & $7144813(63.29)$ \\
\hline TRIPURA & 693469 & $99714(14.38)$ & $338096(48.75)$ & $437810(63.13)$ \\
\hline BIHAR & 17829066 & $37657(0.21)$ & $10876054(61)$ & $10913711(61.21)$ \\
\hline MIZORAM & 111626 & $512(0.46)$ & $66499(59.57)$ & $67011(60.03)$ \\
\hline $\begin{array}{l}\text { DADRA \& NAGAR } \\
\text { HAVELI }\end{array}$ & 45352 & $298(0.66)$ & $25378(55.96)$ & $25676(56.61)$ \\
\hline JHARKHAND & 5044234 & $52045(1.03)$ & $2694061(53.41)$ & $2746106(54.44)$ \\
\hline MANIPUR & 448163 & $4963(1.11)$ & $236653(52.81)$ & $241616(53.91)$ \\
\hline ANDHRA PRADESH & 9344157 & $59470(0.64)$ & $4822097(51.61)$ & $4881567(52.24)$ \\
\hline RAJASTHAN & 10223073 & $72091(0.71)$ & $5165212(50.53)$ & $5237303(51.23)$ \\
\hline ASSAM & 5743835 & $33451(0.58)$ & $2892859(50.36)$ & $2926310(50.95)$ \\
\hline TAMILNADU & 10088119 & $38549(0.38)$ & 4704939 (46.64) & $4743488(47.02)$ \\
\hline MAHARASHTRA & 13736107 & $223002(1.62)$ & $6002793(43.7)$ & $6225795(45.32)$ \\
\hline GUJARAT & 6920473 & $31216(0.45)$ & $2967972(42.89)$ & $2999188(43.34)$ \\
\hline UTTAR PRADESH & 26015544 & $68190(0.26)$ & $10381289(39.9)$ & $10449479(40.17)$ \\
\hline TELANGANA & 5643187 & $13543(0.24)$ & $2135883(37.85)$ & $2149426(38.09)$ \\
\hline SIKKIM & 88723 & $235(0.26)$ & $33480(37.74)$ & 33715 (38) \\
\hline $\begin{array}{l}\text { ARUNACHAL } \\
\text { PRADESH }\end{array}$ & 201510 & $3559(1.77)$ & 72873 (36.16) & 76432 (37.93) \\
\hline JAMMU \& KASHMIR & 1601606 & $13791(0.86)$ & $586345(36.61)$ & $600136(37.47)$ \\
\hline KARNATAKA & 8048664 & $30074(0.37)$ & 2836539 (35.24) & $2866613(35.62)$ \\
\hline PUDUCHERRY & 115249 & $311(0.27)$ & $40336(35)$ & $40647 \quad(35.27)$ \\
\hline HARYANA & 2969509 & $6519(0.22)$ & $997129(33.58)$ & $1003648(33.8)$ \\
\hline DAMAN AND DIU & 31795 & $3519(11.07)$ & $6313(19.86)$ & $9832(30.92)$ \\
\hline UTTARAKHAND & 1479742 & $4726(0.32)$ & $429888(29.05)$ & $434614(29.37)$ \\
\hline CHANDIGARH & 15657 & $10(0.06)$ & $3925(25.07)$ & $3935(25.13)$ \\
\hline
\end{tabular}


IRA-International Journal of Management \& Social Sciences

\begin{tabular}{|l|r|r|r|r|} 
PUNJAB & 3269467 & $8004(0.24)$ & $778245(23.8)$ & $786249(24.05)$ \\
\hline ANDAMAN \& NIs & 68481 & $168(0.25)$ & $15976(23.33)$ & $16144(23.57)$ \\
\hline KERALA & 6319215 & $14289(0.23)$ & $1469167(23.25)$ & $1483456(23.48)$ \\
\hline $\begin{array}{l}\text { HIMACHAL } \\
\text { PRADESH }\end{array}$ & 1263500 & $1931(0.15)$ & $259673(20.55)$ & $261604(20.7)$ \\
\hline LAKSHADWEEP & 10929 & $13(0.12)$ & $1455(13.31)$ & $1468(13.43)$ \\
\hline GOA & 220731 & $135(0.06)$ & $23816(10.79)$ & $23951(10.85)$ \\
\hline NCT OF DELHI & 1051097 & $1144(0.11)$ & $89740(8.54)$ & $90884(8.65)$ \\
\hline \multicolumn{4}{|l}{} \\
\hline
\end{tabular}

Exclusion group and to exclude those households having two rooms with pucca walls and roof. And also took only seven parameters for exclusion instead of 13 by GoI/MoRD. The results are given below (Table.4).

\section{SECC Different Criteria and a Combined View}

A comparison of the results of using three different exclusion criterions reveals discrepant findings (see Table.4). The MoRD's official SECC norm based findings come out with much lesser per centages of exclusion, inclusion and deprivations than that of Abhijit Sen based norms of exclusion. It would be presumed that Sen wanted a larger number of households be brought into the deprivation and inclusion categories of population may be a more proactive broad perception and orientation. To counter Sen's liberal approach a stringent norm of exclusion was suggested by the Adviser MoRD and lower poverty figures arrived at (see Table.4). So the lesson is that by applying different exclusion norms, the intensity and base of coverage of multidimensional poverty arrived can be subjected to variation. Therefore there is a need to take utmost care in applying the exclusion norms arbitrarily by State Governments. If State specific norms are applied to suit local differences then at all India level there will be need to take stock of these.

Table 4: SECC Different Criteria a Combined View

\begin{tabular}{|l|c|c|c|}
\hline \multicolumn{1}{|c|}{ Particulars } & SECC Exclusion & Modified Exclusion & $\begin{array}{c}\text { A .Sen- Two Stage } \\
\text { Exclusion }\end{array}$ \\
\hline Total Rural Households & 17.96 Crore & 17.96 Crore & 17.96 Crore \\
\hline Households Excluded & 07.06 Crore $(39.37 \%)$ & 7.56 Crore $(42.06 \%)$ & 2.72 Crore $(15.14 \%)$ \\
\hline Automatically Included & 0.16 Crore $(0.92 \%)$ & 0.17 Crore $(0.94 \%)$ & 19.54 lakh $(1.09 \%)$ \\
\hline Considered for Deprivation & 10.71 Crore $(59.71 \%)$ & 10.24 Crore $(56.99 \%)$ & 15.04 Crore $(83.77 \%)$ \\
\hline Not reporting Deprivation & 02.01 Crore $(11.20 \%)$ & 1.99 Crore $(11.07 \%)$ & 4.02 Crore $(22.40 \%)$ \\
\hline Household With Deprivations & 08.70 Crore $(48.51 \%)$ & 8.25 Crore $(45.92 \%)$ & 11.02 Crore $(61.37 \%)$ \\
\hline $\begin{array}{l}\text { Households with at least 1 } \\
\text { Deprivation }\end{array}$ & 8.70 Crore $(48.51 \%)$ & 8.25 Crore $45.92 \%$ & 11.02 Crore $(61.37 \%)$ \\
\hline $\begin{array}{l}\text { Households with at least 2 } \\
\text { Deprivation }\end{array}$ & 5.34 Crore $(29.78 \%)$ & 5.11 Crore $(28.44 \%$ & 6.20 Crore $(34.57 \%)$ \\
\hline $\begin{array}{l}\text { Households with at least 3 } \\
\text { Deprivation }\end{array}$ & 2.35 Crore $(13.09 \%)$ & 2.29 Crore $12.75 \%$ & 2.57 Crore $(14.33 \%)$ \\
\hline $\begin{array}{l}\text { Households with at least 4 } \\
\text { Deprivation }\end{array}$ & 0.69 Crore $(3.87 \%)$ & 0.69 Crore $(3.85 \%$ & 0.74 Crore $(4.10 \%)$ \\
\hline $\begin{array}{l}\text { Households with at least 5 } \\
\text { Deprivation }\end{array}$ & 0.14 Crore $(0.80 \%)$ & 0.14 Crore $(0.80 \%$ & 0.15 Crore $(0.83 \%)$ \\
\hline $\begin{array}{l}\text { Households with at least 6 } \\
\text { Deprivation }\end{array}$ & 0.02 Crore $(0.14 \%)$ & 2.53 lakh $(0.14 \%$ & 2.54 lakh $(0.14 \%)$ \\
\hline $\begin{array}{l}\text { Households with all the 7 } \\
\text { Deprivation }\end{array}$ & $12,901(0.01 \%)$ & $13,208(0.01 \%)$ & $13,215(0.01 \%)$ \\
\hline
\end{tabular}


The number of households reporting at least one of the seven deprivation as per these three approaches are as follows; as by SECC norm it is at 49\%, as per A..Sen's norm it is at $62 \%$ and as per EA MoRD's norm it is at $46 \%$. Similarly, the households that are excluded as per these three respective norms are at 39,15 and 42 per centages ( see Table.4). The stringent norm applied here by that of the Adviser MoRD may become as a trend setter as the field realities in rural India have undergone substantial changes with regard to the socio economic conditions enjoyed by the people. Besides, the market enabled advantages out of economic growth and development and the benefits flowing out of government's welfare programmes aimed at to benefit weaker sections also may have tended to lessen the incidence of poverty in the country.

\section{SECC-Number of Poor Households VS with NSSO Rural Poverty Ratios}

The NSSO based estimates of per centage of rural poor persons as arrived at by using the S.Tendulker and C.Rangarajan methods need be compared with that of SECC numbers of deprived households (see Table.5). Given the debate that as per C Rangarajan's methodology based estimates, the poverty ratio increased as opposed to S.Tendulker findings that poverty declined in India, and the SECC indicates that the per centage of households that are poor are much more than that of S Tendulkar and C Rangarajan's poverty ratios for the country. It is for the Government of India to take up these SECC findings and work out strategies to eradicate multi dimensional poverty in the country. In Arunachal Pradesh the Rangarajan poverty ratio is only marginally higher than that of SECC poor households. In the NCT of Delhi the SECC per centage of poor households is lower than that of NSSO based estimates, suggests that the poverty may have declined in the rural areas of capital city of the country and in Arunachal. It is surmised here that the percentages of poor persons and that of poor households are comparable for the purposes of our analysis.

\section{Income and Malnutrition Based Poverty VS SECC}

The estimates of multidimensional poverty arrived at by Radhakrishna et al by using the NFHS based nutrition data on the select 3 variables; the per centage of poor households among the households with a woman and child below five years of age; the per centage of households with stunted child below 5 years of age; and per centage of chronic energy deficiency females are here compared with that of SECC based per centage of households with at least one inclusion and deprivation. The following findings deserve attention. Only in the States of Gujarat, Himachal, Karnataka, Maharashtra, Uttar Pradesh, and Uttarakhand the SECC based poverty figures are lower than the former (see table.6). It may be noted that, for analysis of multidimensional poverty Radhakrishna et al could only generate data for twenty States/UTs, while SECC has data on all 36 States/UTs of the country.

Table 5: SECC V/S NSSO Based Estimates of Poverty

\begin{tabular}{|l|c|c|c|}
\hline States/ UTs Name & $\begin{array}{l}\text { \% of Total of at least one } \\
\text { of Inclusion }+ \\
\text { Deprivation HHs }\end{array}$ & $\begin{array}{l}\text { NSSO \% of Poor } \\
\text { persons 2011-12 } \\
\text { (Tendulkar })\end{array}$ & $\begin{array}{l}\text { NSSO \% of Poor } \\
\text { persons 2011-12 } \\
\text { (Rangarajan ) }\end{array}$ \\
\hline All India & 49 & 26 & 30.9 \\
\hline A \& N ISLANDS & 24 & 2 & 6.6 \\
\hline ANDHRA PRADESH & 52 & 11 & 12.7 \\
\hline ARUNACHAL PRADESH & 38 & 34 & 39.3 \\
\hline ASSAM & 51 & 34 & 42 \\
\hline BIHAR & 61 & 34 & 40.1 \\
\hline CHANDIGARH & 25 & 2 & 49.2 \\
\hline CHHATTISGARH & 72 & 45 & 55.2 \\
\hline DADRA \& NAGAR HAVELI & 57 & 63 & 0 \\
\hline DAMAN AND DIU & 31 & 0 & 1.4 \\
\hline GOA & 11 & 7 & \\
\hline
\end{tabular}




\begin{tabular}{|l|c|c|c|}
\hline GUJARAT & 43 & 22 & 31.4 \\
\hline HARYANA & 34 & 12 & 11 \\
\hline HIMACHAL PRADESH & 21 & 9 & 11.1 \\
\hline JAMMU \& KASHMIR & 37 & 12 & 12.6 \\
\hline JHARKHAND & 54 & 41 & 45.9 \\
\hline KARNATAKA & 36 & 25 & 19.8 \\
\hline KERALA & 23 & 9 & 7.3 \\
\hline LAKSHADWEEP & 13 & 0 & 0.6 \\
\hline MADHYA PRADESH & 63 & 36 & 45.2 \\
\hline MAHARASHTRA & 45 & 24 & 22.5 \\
\hline MANIPUR & 54 & 39 & 34.9 \\
\hline Meghalaya & 68 & 12.5 & 26.3 \\
\hline MIZORAM & 60 & 35 & 33.7 \\
\hline NAGALAND & 65 & 20 & 6.1 \\
\hline NCT OF DELHI & 9 & 13 & 11.9 \\
\hline ODISHA & 67 & 36 & 47.8 \\
\hline PUDUCHERRY & 35 & 17 & 5.9 \\
\hline PUNJAB & 24 & 8 & 7.4 \\
\hline RAJASTHAN & 51 & 16 & 21.4 \\
\hline SIKKIM & 38 & 10 & 20 \\
\hline TAMILNADU & 47 & 16 & 24.3 \\
\hline TELANGANA & 38 & 0 & 0 \\
\hline TRIPURA & 63 & 17 & 22.5 \\
\hline UTTAR PRADESH & 40 & 30 & 38.1 \\
\hline UTTARAKHAND & 29 & 12 & 12.6 \\
\hline WEST BENGAL & 65 & 23 & 30.1 \\
\hline
\end{tabular}

The union of households from two sets of data (with poverty and child malnutrition) and with that of three sets of data (with poverty, child malnutrition and chronic energy deficiency in females) as presented by Radhakrishna et al when compared with indicate that the SECC multidimensional poverty figures are at lower levels in all the 21 States (see Table.6).

The intersection of households from two separate sets of data namely; firstly with poverty and child malnutrition and secondly with that of poverty, child malnutrition and chronic energy deficiency in females ; the poverty levels arrived at are much lower than that of SECC poverty figures ( see Table. 6) in all the 21 Sates. This type of poverty can be rightly called the abject poverty figures from nutrition based data. The extreme abject poverty (intersection of Poverty, Child malnutrition and CED females) at the highest levels is at 26, 22 and 21 per centages respectively in the States of Bihar, Chhattisgarh, and Odisha and are lower than that of SECC multi-dimensional poverty figures. And according to a less stringent version of abject poverty (intersection of poverty with child malnutrition), it is at 49,40,39,38, 35,34, and 32 per centages respectively in the States/UTs of Bihar, Odisha, Madhya Pradesh, Chhattisgarh, Uttar Pradesh, and Jharkhand. And these abject poverty figures are lesser than that of SECC multi- dimensional poverty figures. We will see below how these abject poverty figures compare with similar type of intersection data on automatic inclusion households with deprivations data of SECC (see Table.8).

The S.Tendulker figures of poverty ratio for the year 2004-05 are higher than that of the SECC 2011 poverty, only for the Sates of Himachal, Maharashtra, Uttar Pradesh and Uttarakhand, while for the rest the latter is higher. This reinforces the findings that SECC multi dimensional poverty in general is much higher than that of NSSO based poverty ratios for over long periods, till day. 
When the SECC data on four deprivation parameters, D2,D3,D4 and D6 is placed across the nutrition based abject poverty variables, it is noted that only the D6 moves closer to with the abject poverty figures arrived at by Radhakrishna et al ( see Table.6; Col 11,12,\&13)) and the former is invariably high.

Conceptually, it is expected that as a first step, the nutrition based multi-dimensional poverty estimates arrived at by Radhakrishna et al has its logic in the thinking that the percentage of poor households among the households with a women and child below 5 years of age; the per centage of households with stunted child below 5 years of age; and the per centage of chronic energy deficient (CED) females would depict the multi dimensionality of poverty in a robust manner. Secondly they have tried to bring in two more concepts to depict the multi dimensionality of poverty. (i). They worked out the per centage of poor households for a given union of two separate sets of data; i.e. union of poor households with child malnutrition households and that of poverty with child malnutrition and chronically energy deficient females. And (ii) the intersection of households with two sets, i.e. poverty and child malnutrition and poverty, child malnutrition and CED females were attempted.

To the above set of nutrition based approach to analysis of poverty, the SECC deprivations data pertaining to parameters D2, D3, D4 and D6 is hypothesized as much 


\begin{tabular}{|c|c|c|c|c|c|c|c|c|c|c|c|c|c|}
\hline \multicolumn{14}{|c|}{ Table 6: Multidimensional Poverty Estimates by Pooling NSSO \& NFHS Data by Radhakrishna et all VS SECC 2011} \\
\hline \multirow{2}{*}{$\begin{array}{c}\text { State } \\
\text { Name }\end{array}$} & \multirow[b]{2}{*}{$\begin{array}{l}\% \text { of poor } \\
\text { persons } \\
\text { Below } \\
\text { Poverty } \\
\text { Line ( for } \\
2004-05 \text { as } \\
\text { by } \\
\text {.Tendulkar } \\
\text { Methodolo } \\
\text { gy) }\end{array}$} & \multirow[b]{2}{*}{$\begin{array}{c}\text { Per } \\
\text { centa } \\
\text { ge of } \\
\text { poor } \\
\text { HH } \\
\text { amon } \\
\text { g the } \\
\text { HH } \\
\text { with a } \\
\text { Wom } \\
\text { an \& } \\
\text { a } \\
\text { Child } \\
\text { Belo } \\
\text { w } 5 \\
\text { years } \\
\text { of } \\
\text { Age }\end{array}$} & \multirow[b]{2}{*}{$\begin{array}{c}\text { D3- In } \\
\text { SECC } \\
\text { the \% of } \\
\text { Female } \\
\text { headed } \\
\text { househol } \\
\text { ds with } \\
\text { no adult } \\
\text { male } \\
\text { member } \\
\text { bet 16- } \\
59 \text { age }\end{array}$} & \multirow[b]{2}{*}{$\begin{array}{l}\text { \% of } \\
\text { HH } \\
\text { with } \\
\text { stunt } \\
\text { ed } \\
\text { Child } \\
\text { belo } \\
\text { w } 5 \\
\text { years } \\
\text { of } \\
\text { Age }\end{array}$} & \multirow[b]{2}{*}{$\begin{array}{c}\text { D4-In } \\
\text { SECC } \\
\% \text { of } \\
\text { HHs } \\
\text { with } \\
\text { disabl } \\
\text { ed } \\
\text { memb } \\
\text { er and } \\
\text { no } \\
\text { able } \\
\text { bodied } \\
\text { adult } \\
\text { memb } \\
\text { er }\end{array}$} & \multirow[b]{2}{*}{$\begin{array}{c}\% \text { of } \\
\text { Chronic } \\
\text { Energy } \\
\text { Deficien } \\
\text { cy } \\
\text { (CED) } \\
\text { Females }\end{array}$} & \multicolumn{2}{|c|}{ Union of Households } & \multirow[b]{2}{*}{$\begin{array}{c}\text { D2- } \\
\text { No } \\
\text { adult } \\
\text { memb } \\
\text { er } \\
\text { betwe } \\
\text { en age } \\
16-59\end{array}$} & \multicolumn{2}{|c|}{ Intersection of HHs } & \multirow[b]{2}{*}{$\begin{array}{l}\text { D6- } \\
\text { No } \\
\text { litera } \\
\text { te } \\
\text { adult } \\
\text { abov } \\
\text { e 25 } \\
\text { years }\end{array}$} & \multirow[b]{2}{*}{$\begin{array}{c}\% \text { of Poor } \\
\text { HHs in } \\
\text { SECC(At } \\
\text { least one } \\
\text { AI+ one } \\
\text { Deprivati } \\
\text { on) }\end{array}$} \\
\hline & & & & & & & $\begin{array}{l}\text { With } \\
\text { Poverty } \\
\text { and Child } \\
\text { Malnutriti } \\
\text { on }\end{array}$ & $\begin{array}{l}\text { with } \\
\text { Poverty, } \\
\text { Child } \\
\text { Malnutriti } \\
\text { on and } \\
\text { CED in } \\
\text { Females }\end{array}$ & & $\begin{array}{l}\text { with } \\
\text { Poverty, } \\
\text { Child } \\
\text { Malnutriti } \\
\text { on }\end{array}$ & $\begin{array}{l}\text { with Poverty, } \\
\text { Child } \\
\text { malnutrition, } \\
\text { and CED } \\
\text { Females }\end{array}$ & & \\
\hline (1) & $(2)$ & (3) & (4) & (5) & (6) & (7) & (8) & (9) & (10) & (11) & (12) & $(13)$ & (14) \\
\hline All India & 41.8 & 53.4 & 3.63 & 53.3 & 0.4 & 43.7 & 75.1 & 83.3 & 3.63 & 31.6 & 16.3 & 23.61 & 49 \\
\hline A\&NIs & - & - & 2.57 & - & 0.27 & - & - & - & 2.02 & - & & 7.76 & 24 \\
\hline Andhra P & 32.3 & 42.8 & 6.67 & 44 & 0.36 & 47.7 & 65.7 & 78.3 & 6.1 & 21.1 & 11.1 & 28.73 & 52 \\
\hline Arunachal & - & - & 1.33 & - & 0.34 & - & - & - & 1.33 & - & - & 19.55 & 38 \\
\hline Assam & 36.4 & 46.5 & 3.36 & 47.2 & 0.40 & 42.7 & 68.4 & 80.2 & 1.49 & 25.3 & 13.4 & 24.83 & 51 \\
\hline Bihar & 55.7 & 68.9 & 2.96 & 65.2 & 0.48 & 49.3 & 85.5 & 90.2 & 3.42 & 48.6 & 26.4 & 34.12 & 61 \\
\hline $\begin{array}{l}\text { Chandigar } \\
\mathrm{h}\end{array}$ & - & - & 0.67 & - & 0.04 & - & - & - & 0.42 & - & - & 15.49 & 25 \\
\hline $\begin{array}{l}\text { Chhattisg } \\
\text { arh }\end{array}$ & 55.1 & 62.5 & 6.79 & 62.6 & 0.81 & 50.3 & 86.7 & 92.5 & 6.47 & 38.3 & 22.1 & 33.88 & 72 \\
\hline $\begin{array}{l}\text { Dadra \& } \\
\mathrm{NH}\end{array}$ & - & - & 1.87 & - & 0.13 & - & - & - & 1.75 & - & - & 30.7 & 57 \\
\hline $\begin{array}{l}\text { Daman \& } \\
\text { D }\end{array}$ & - & - & 1.52 & - & 0.13 & - & - & - & 1.05 & - & - & 11.55 & 31 \\
\hline Goa & - & - & 2.38 & - & 0.16 & - & - & - & 1.38 & - & - & 4.01 & 11 \\
\hline Gujarat & 39.1 & 50.9 & 2.84 & 58.9 & 0.28 & 50 & 77.8 & 86 & 3.35 & 32 & 16.2 & 17.03 & 43 \\
\hline Haryana & 24.8 & 31.4 & 1.74 & 53.6 & 0.19 & 39.7 & 64.1 & 74.3 & 1.89 & 20.9 & 11.1 & 16.68 & 34 \\
\hline Himachal & 25 & 34.7 & 2.97 & 41.5 & 0.31 & 35.1 & 57.7 & 71.6 & 2.71 & 18.53. & 8.3 & 7.77 & 21 \\
\hline
\end{tabular}


IRA-International Journal of Management \& Social Sciences

\begin{tabular}{|c|c|c|c|c|c|c|c|c|c|c|c|c|c|}
\hline $\begin{array}{l}\text { Jammu\& } \\
\text { K }\end{array}$ & 14.1 & 23.4 & 1.66 & 40.2 & 0.36 & 33 & 51.9 & 66.3 & 1.83 & 11.8 & 4.3 & 25.17 & 37 \\
\hline Jharkhand & 51.6 & 60.9 & 3.13 & 54.4 & 0.33 & 49.7 & 81.3 & 90.5 & .2 .61 & 34.1 & 18.5 & 28.4 & 54 \\
\hline Karnataka & 37.5 & 51 & 4.75 & 42.2 & 0.25 & 43 & 70.4 & 79.7 & $2 . .90$ & 22.7 & 11.8 & 18.95 & 36 \\
\hline Kerala & 20.2 & 24.4 & 3.65 & 27.1 & 0.19 & 18 & 40.6 & 48 & 2.1 & 10.9 & 3.6 & 1.81 & 23 \\
\hline $\begin{array}{l}\text { Lakshadw } \\
\text { ep }\end{array}$ & - & - & 2.11 & - & 0.2 & - & - & - & 0.7 & - & - & 0.64 & 13 \\
\hline $\begin{array}{l}\text { Madhya } \\
\text { Prad }\end{array}$ & 53.6 & 64.5 & 4.07 & 59.1 & 0.73 & 46.6 & 85 & 90.8 & 5.18 & 38.6 & 18.9 & 33.13 & 63 \\
\hline $\begin{array}{l}\text { Maharash } \\
\text { tra }\end{array}$ & 47.9 & 56 & 4.83 & 46.2 & 0.35 & 48.7 & 72.5 & 83.8 & 5.09 & 29.8 & 18.3 & 17.56 & 45 \\
\hline Manipur & - & - & 2.97 & - & 0.19 & - & - & - & 1.38 & - & - & 13.77 & 54 \\
\hline $\begin{array}{l}\text { Meghalay } \\
\text { a }\end{array}$ & - & - & 5.59 & - & 0.4 & - & - & - & 1.67 & - & - & 25.87 & 68 \\
\hline Mizoram & - & - & 3.32 & - & 0.21 & - & - & - & 2.11 & - & - & 16.37 & 60 \\
\hline Nagaland & - & - & 4.42 & - & 0.44 & - & - & - & $2 . .87$ & - & - & 21.4 & 65 \\
\hline $\begin{array}{l}\text { NCT } \\
\text { Delhi }\end{array}$ & & & 0.40 & & 0.05 & & & & 0.34 & & & 3.57 & 9 \\
\hline Odisha & 60.8 & 69.5 & 5.25 & 49.3 & 0.59 & 46.3 & 79.9 & 86.1 & 4.88 & 38.9 & 20.5 & 27.79 & 67 \\
\hline $\begin{array}{l}\text { Puducherr } \\
\text { y }\end{array}$ & - & - & 6.05 & - & 0.26 & - & - & - & 3.98 & - & - & 11.09 & 35 \\
\hline Punjab & 22.1 & 26.7 & 1.18 & 43.7 & 0.17 & 23.5 & 53.9 & 63.4 & 1.68 & 16.4 & 5.6 & 12.59 & 24 \\
\hline Rajasthan & 35.8 & 46 & 3.08 & 53.2 & 0.77 & 40 & 73.4 & 83.3 & 3.2 & 25.8 & 11 & 31.39 & 51 \\
\hline Sikkim & - & - & 2.8 & - & & - & & - & 1.74 & - & - & 13.5 & 38 \\
\hline $\begin{array}{l}\text { Tamil } \\
\text { Nadu }\end{array}$ & 37.5 & 44.5 & 6.84 & 33.3 & & 33.5 & 60.6 & 69.7 & 6.28 & 17.1 & 8.2 & 16.37 & 47 \\
\hline Telangana & - & - & 5.23 & - & & - & - & - & 4.62 & - & - & 25.3 & 38 \\
\hline Tripura & - & - & 4.08 & & & - & - & - & 2.47 & - & - & 12.51 & 63 \\
\hline $\begin{array}{l}\text { Uttar } \\
\text { Pradesh }\end{array}$ & 42.7 & 54.5 & 2.02 & 58.9 & & 40.5 & 79.9 & 86.5 & 2.47 & 33.5 & 16.3 & 20.29 & 40 \\
\hline $\begin{array}{l}\text { Uttarakha } \\
\text { nd }\end{array}$ & 35.1 & 47.6 & 5.54 & 54 & & 35.8 & 71.5 & 78.7 & 4.49 & 30.1 & 12.4 & 12.88 & 29 \\
\hline $\begin{array}{l}\text { West } \\
\text { Bengal }\end{array}$ & 38.2 & 49.7 & 3.55 & 51.6 & & 49.9 & 71.1 & 82.2 & 2.41 & 30.2 & 17.5 & 25.73 & 65 \\
\hline
\end{tabular}


Closer in content and concern with the former and hence these data have been put together (see Table.6) to scrutinize the outcomes. The D2 refers to the households with no adult member between age 16 to 59; D3 refers to the per centage of female headed households with no adult male member between 16 to 59 age; D4 refers to per centage of households with disabled member and no able bodied adult member; and D6 refers to households with no literate adult above 25 years. The results indicate that in general the multi dimensional nutrition based poverty figures from NFHS data and that of SECC do not strictly match or move together. However, the multidimensional poverty arrived at from NFHS data is much higher than that out of SECC. How the abject poverty estimates out of NFHS compare with similar SECC data and is explained below. These results indicate that these multidimensional poverty figures of NFHS and SECC are much higher than that of NSSO based estimates.

\section{Abjectly Poor as Per SECC}

In SECC, the first set of abjectly poor are those households that are automatically included and plus those with the enlisted seven deprivations. While ranking the households to prioritize for beneficiary selection etc the five automatically included categories would be placed atop followed by those having the largest number of deprivations. However, the sub set of those automatically included but also qualifying for any of the seven derivations would come up to constitute the most vulnerable poor households ( see Table.7). Now, in the schema of SECC, these will have to be at first placed atop the list; however, this scenario was so far not assessed and presented in SECC, but needs to be. Let us also see how these are matching with those of the NFSH based abject poverty.

Per centage of automatically included (AI) households reporting any of the seven deprivations are to be considered as abjectly poor. Now, the intersection of AI households with D6, i.e. AI households with no illiterate adult above 25 years; are in the range of 31 to 70 per centages while it is in the range of 4 to 39 per centages with the abject poverty figures arrived at from SECC and NFHS ( see table.8. Col 8 on SECC and Table 6, cols $11 \& 12$ of NFHS) database of respective States. This implies that incidence of illiteracy figures a prominent place as a major determinant of abject poverty and it is more so than that of nutrition based abject poverty rates.

The abject poverty arrived at by intersection of Automatic Inclusion households with deprivation three (D3) are at higher rates in 17 out of 22 States with NFHS data (see col 11\&12 of table 6 and col $02 \& 03$ of table 8). The levels of abject poverty from SECC with respect to D2, and D4 are at lower rates than in majority of NFHS States (see col.7\&5 of table.8 with col.11\&12 of table 6).Incidence of abject poverty is more among those automatically included households having deprivations D5, D6, D7, D1 at the rates of 63, 61, 36 and 35 per centages respectively ( see Table.7).

Thus in general, the abject poverty captured by SECC is more broad based and severe than its incidence as found in NFHS data. Over the period 2004-05 to 2011, the abject poverty has increased in rural India. 
IRA-International Journal of Management \& Social Sciences

\begin{tabular}{|c|c|c|c|c|c|c|c|c|c|c|}
\hline \multicolumn{11}{|c|}{ Table 7: Automatic Inclusion by Deprivations } \\
\hline \multirow{2}{*}{ State code } & \multirow{2}{*}{ State name } & \multirow{2}{*}{$\begin{array}{c}\text { Total } \\
\text { Household }\end{array}$} & \multirow[b]{2}{*}{ Total } & \multicolumn{7}{|c|}{ 1- to 5 Automatically Included Households by D1 to D7 Deprivations Criteria } \\
\hline & & & & D1 & D2 & D3 & D4 & D5 & D6 & D7 \\
\hline 1 & JAMMU \& KAS & 1601606 & 13791 & $19.58 \%$ & $9.82 \%$ & $11.08 \%$ & $5.01 \%$ & $46.93 \%$ & $66.90 \%$ & $13.53 \%$ \\
\hline 2 & HIMACHAL PRA & 1263500 & 1931 & $7.15 \%$ & $24.24 \%$ & $20.97 \%$ & $6.47 \%$ & $34.85 \%$ & $45.57 \%$ & $1.14 \%$ \\
\hline 3 & PUNJAB & 3269467 & 8004 & $12.68 \%$ & $18.45 \%$ & $11.38 \%$ & $4.94 \%$ & $47.14 \%$ & $61.39 \%$ & $36.37 \%$ \\
\hline 4 & CHANDIGARH & 15657 & 10 & $0.00 \%$ & $0.00 \%$ & $10.00 \%$ & $0.00 \%$ & $30.00 \%$ & $40.00 \%$ & $0.00 \%$ \\
\hline 5 & UTTARAKHAND & 1479742 & 4726 & $11.05 \%$ & $12.27 \%$ & $13.01 \%$ & $2.73 \%$ & $55.44 \%$ & $39.29 \%$ & $31.27 \%$ \\
\hline 6 & HARYANA & 2969509 & 6519 & $17.30 \%$ & $21.45 \%$ & $13.67 \%$ & $4.42 \%$ & $34.30 \%$ & $65.93 \%$ & $12.16 \%$ \\
\hline 7 & NCT OF DELHI & 1051097 & 1127 & $3.99 \%$ & $8.78 \%$ & $7.01 \%$ & $3.90 \%$ & $26.26 \%$ & $39.31 \%$ & $14.20 \%$ \\
\hline 8 & RAJASTHAN & 10223073 & 72091 & $39.07 \%$ & $15.41 \%$ & $12.27 \%$ & $8.29 \%$ & $54.38 \%$ & $68.98 \%$ & $20.52 \%$ \\
\hline 9 & UTTAR PRA & 26015544 & 68190 & $27.67 \%$ & $14.36 \%$ & $10.31 \%$ & $3.72 \%$ & $41.94 \%$ & $54.70 \%$ & $28.59 \%$ \\
\hline 10 & BIHAR & 17829066 & 37657 & $41.26 \%$ & $22.76 \%$ & $22.72 \%$ & $8.73 \%$ & $17.06 \%$ & $65.75 \%$ & $22.72 \%$ \\
\hline 11 & SIKKIM & 88723 & 235 & $5.11 \%$ & $5.53 \%$ & $5.53 \%$ & $4.68 \%$ & $58.30 \%$ & $29.36 \%$ & $8.09 \%$ \\
\hline 12 & ARUNACHAL Pra. & 201510 & 3559 & $38.75 \%$ & $3.09 \%$ & $6.77 \%$ & $1.29 \%$ & $96.40 \%$ & $46.53 \%$ & $1.60 \%$ \\
\hline 13 & NAGALAND & 284310 & 969 & $8.67 \%$ & $32.30 \%$ & $28.69 \%$ & $17.75 \%$ & $97.52 \%$ & $51.91 \%$ & $10.53 \%$ \\
\hline 14 & MANIPUR & 448163 & 4963 & $1.13 \%$ & $3.08 \%$ & $6.39 \%$ & $0.58 \%$ & $96.15 \%$ & $44.27 \%$ & $2.46 \%$ \\
\hline 15 & MIZORAM & 111626 & 512 & $14.45 \%$ & $13.87 \%$ & $17.77 \%$ & $2.54 \%$ & $99.02 \%$ & $56.05 \%$ & $7.23 \%$ \\
\hline 16 & TRIPURA & 693469 & 72961 & $29.92 \%$ & $4.93 \%$ & $5.52 \%$ & $0.56 \%$ & $96.47 \%$ & $35.73 \%$ & $33.40 \%$ \\
\hline 17 & MEGHALAYA & 485897 & 1224 & $15.03 \%$ & $14.05 \%$ & $25.41 \%$ & $9.64 \%$ & $76.39 \%$ & $47.71 \%$ & $14.79 \%$ \\
\hline 18 & ASSAM & 5743835 & 33451 & $40.33 \%$ & $22.16 \%$ & $41.52 \%$ & $9.04 \%$ & $10.48 \%$ & $62.10 \%$ & $2.97 \%$ \\
\hline 19 & WEST BENGAL & 15756750 & 203209 & $56.66 \%$ & $38.01 \%$ & $49.90 \%$ & $11.45 \%$ & $30.19 \%$ & $69.84 \%$ & $5.15 \%$ \\
\hline 20 & JHARKHAND & 5044234 & 52045 & $34.06 \%$ & $10.11 \%$ & $10.85 \%$ & $2.76 \%$ & $75.34 \%$ & $62.41 \%$ & $19.60 \%$ \\
\hline 21 & ODISHA & 8624075 & 117893 & $40.16 \%$ & $19.09 \%$ & $22.27 \%$ & $6.36 \%$ & $53.95 \%$ & $63.92 \%$ & $32.97 \%$ \\
\hline 22 & CHHATTISGARH & 4540999 & 112084 & $46.86 \%$ & $17.18 \%$ & $17.30 \%$ & $4.40 \%$ & $83.74 \%$ & $63.19 \%$ & $30.60 \%$ \\
\hline 23 & MADHYA PRA & 11288946 & 396787 & $42.33 \%$ & $12.15 \%$ & $9.98 \%$ & $3.43 \%$ & $79.18 \%$ & $65.83 \%$ & $52.48 \%$ \\
\hline 24 & GUJARAT & 6920473 & 31216 & $20.79 \%$ & $18.88 \%$ & $14.16 \%$ & $4.46 \%$ & $45.83 \%$ & $50.68 \%$ & $37.53 \%$ \\
\hline 25 & DAMAN \& DIU & 31795 & 3519 & $0.77 \%$ & $2.19 \%$ & $2.73 \%$ & $0.14 \%$ & $7.10 \%$ & $31.63 \%$ & $15.57 \%$ \\
\hline 26 & DADRA N\&H & 45352 & 298 & $7.05 \%$ & $3.36 \%$ & $3.02 \%$ & $0.34 \%$ & $68.79 \%$ & $43.62 \%$ & $12.75 \%$ \\
\hline
\end{tabular}


IRA-International Journal of Management \& Social Sciences

\begin{tabular}{|c|c|c|c|c|c|c|c|c|c|c|}
\hline 27 & MAHARASHTRA & 13834092 & 227382 & $17.71 \%$ & $9.99 \%$ & $10.26 \%$ & $1.85 \%$ & $68.46 \%$ & $50.04 \%$ & $57.42 \%$ \\
\hline 28 & ANDHRA PRA & 9344180 & 59470 & $11.44 \%$ & $13.02 \%$ & $16.99 \%$ & $2.28 \%$ & $73.14 \%$ & $64.63 \%$ & $35.84 \%$ \\
\hline 29 & KARNATAKA & 8048664 & 30074 & $12.33 \%$ & $10.06 \%$ & $13.78 \%$ & $2.50 \%$ & $51.85 \%$ & $51.10 \%$ & $30.80 \%$ \\
\hline 30 & GOA & 220731 & 135 & $11.11 \%$ & $41.48 \%$ & $50.37 \%$ & $20.00 \%$ & $26.67 \%$ & $60.00 \%$ & $5.93 \%$ \\
\hline 31 & LAKSHADWEEP & 10929 & 13 & $7.69 \%$ & $30.77 \%$ & $46.15 \%$ & $15.38 \%$ & $100.00 \%$ & $38.46 \%$ & $7.69 \%$ \\
\hline 32 & KERALA & 6319215 & 14289 & $10.20 \%$ & $32.19 \%$ & $40.69 \%$ & $9.43 \%$ & $38.91 \%$ & $36.31 \%$ & $28.13 \%$ \\
\hline 33 & TAMILNADU & 10088119 & 38549 & $38.34 \%$ & $8.72 \%$ & $11.25 \%$ & $1.02 \%$ & $90.32 \%$ & $59.98 \%$ & $75.80 \%$ \\
\hline 34 & PUDUCHERRY & 115249 & 311 & $25.72 \%$ & $30.87 \%$ & $36.01 \%$ & $2.57 \%$ & $30.87 \%$ & $50.16 \%$ & $4.50 \%$ \\
\hline 35 & ANDAMAN \&NIS & 68481 & 168 & $5.36 \%$ & $9.52 \%$ & $13.10 \%$ & $2.98 \%$ & $51.19 \%$ & $40.48 \%$ & $22.62 \%$ \\
\hline \multirow[t]{2}{*}{36} & TELANGANA & 5643739 & 13543 & $4.53 \%$ & $23.86 \%$ & $23.75 \%$ & $6.18 \%$ & $52.53 \%$ & $73.46 \%$ & $25.46 \%$ \\
\hline & ALL INDIA & 179721817 & 1632905 & $35.53 \%$ & $16.53 \%$ & $18.13 \%$ & $4.80 \%$ & $62.73 \%$ & $60.66 \%$ & $36.02 \%$ \\
\hline
\end{tabular}

Table 8: Abject Poverty with D2,D3,D4.\&D6 of SECC

\begin{tabular}{|c|c|c|c|c|c|c|c|c|c|}
\hline State Name & $\begin{array}{c}\text { D3- In SECC } \\
\text { the } \% \text { of } \\
\text { Female headed } \\
\text { households } \\
\text { with no adult } \\
\text { male member } \\
\text { bet } 16-59 \text { age }\end{array}$ & $\begin{array}{c}\text { \% of D3s } \\
\text { with AIs } \\
\text { HHS }\end{array}$ & $\begin{array}{c}\text { D4-In } \\
\text { SECC \% of } \\
\text { HHs with } \\
\text { disabled } \\
\text { member and } \\
\text { no able } \\
\text { bodied adult } \\
\text { member }\end{array}$ & $\begin{array}{c}\text { \% of D4s } \\
\text { with AIs } \\
\text { HHs }\end{array}$ & $\begin{array}{c}\text { D2- in } \\
\text { SECC \% of } \\
\text { No adult } \\
\text { member } \\
\text { between age } \\
16-59\end{array}$ & $\begin{array}{c}\text { \% of D2s } \\
\text { with AIs } \\
\text { HHs }\end{array}$ & $\begin{array}{c}\text { D6-in } \\
\text { SECC \% of } \\
\text { No literate } \\
\text { adult above } \\
25 \text { years }\end{array}$ & $\begin{array}{c}\text { \% of D6s } \\
\text { with AIs } \\
\text { HHs }\end{array}$ & $\begin{array}{c}\% \text { of Poor HHs } \\
\text { in SECC(At } \\
\text { least one AI+ } \\
\text { one } \\
\text { Deprivation) }\end{array}$ \\
\hline$(1)$ & $(2)$ & (3) & (4) & $(5)$ & $(6)$ & $(7)$ & $(8)$ & (9) & $(10)$ \\
\hline All India & 3.63 & 18 & 0.4 & 5 & 3.63 & 17 & 23.61 & 61 & 49 \\
\hline A\&NIs & 2.57 & 13 & 0.27 & 3 & 2.02 & 10 & 7.76 & 40 & 24 \\
\hline Andhra Pradesh & 6.67 & 17 & 0.36 & 2 & 6.1 & 13 & 28.73 & 65 & 52 \\
\hline Arunachal Pradesh & 1.33 & 7 & 0.34 & 1 & 1.33 & 4 & 19.55 & 47 & 38 \\
\hline Assam & 3.36 & 42 & 0.40 & 9 & 1.49 & 22 & 24.83 & 62 & 51 \\
\hline Bihar & 2.96 & 23 & 0.48 & 9 & 3.42 & 23 & 34.12 & 66 & 61 \\
\hline Chandigarh & 0.67 & 10 & 0.04 & 0 & 0.42 & 0 & 15.49 & 40 & 25 \\
\hline Chhattisgarh & 6.79 & 17 & 0.81 & 4 & 6.47 & 17 & 33.88 & 63 & 72 \\
\hline
\end{tabular}


IRA-International Journal of Management \& Social Sciences

\begin{tabular}{|c|c|c|c|c|c|c|c|c|c|}
\hline Dadra \& NH & 1.87 & 3 & 0.13 & 1 & 1.75 & 2 & 30.7 & 44 & 57 \\
\hline Daman \& Diu & 1.52 & 3 & 0.13 & 1 & 1.05 & 3 & 11.55 & 31 & 31 \\
\hline Goa & 2.38 & 50 & 0.16 & 20 & 1.38 & 41 & 4.01 & 60 & 11 \\
\hline Gujarat & 2.84 & 14 & 0.28 & 4 & 3.35 & 19 & 17.03 & 50 & 43 \\
\hline Haryana & 1.74 & 14 & 0.19 & 4 & 1.89 & 21 & 16.68 & 66 & 34 \\
\hline Himachal Pradesh & 2.97 & 21 & 0.31 & 6 & 2.71 & 24 & 7.77 & 46 & 21 \\
\hline Jammu\& K & 1.66 & 11 & 0.36 & 5 & 1.83 & 10 & 25.17 & 67 & 37 \\
\hline Jharkhand & 3.13 & 11 & 0.33 & 3 & .2 .61 & 10 & 28.4 & 62 & 54 \\
\hline Karnataka & 4.75 & 14 & 0.25 & 3 & $2 . .90$ & 10 & 18.95 & 51 & 36 \\
\hline Kerala & 3.65 & 41 & 0.19 & 9 & 2.1 & 32 & 1.81 & 36 & 23 \\
\hline Lakshadweep & 2.11 & 46 & 0.2 & 15 & 0.7 & 31 & 0.64 & 39 & 13 \\
\hline Madhya Pradesh & 4.07 & 10 & 0.73 & 3 & 5.18 & 13 & 33.13 & 66 & 63 \\
\hline Maharashtra & 4.83 & 10 & 0.35 & 2 & 5.09 & 10 & 17.56 & 50 & 45 \\
\hline Manipur & 2.97 & 6 & 0.19 & 1 & 1.38 & 3 & 13.77 & 44 & 54 \\
\hline Meghalaya & 5.59 & 25 & 0.4 & 10 & 1.67 & 14 & 25.87 & 48 & 68 \\
\hline Mizoram & 3.32 & 18 & 0.21 & 3 & 2.11 & 14 & 16.37 & 56 & 60 \\
\hline Nagaland & 4.42 & 29 & 0.44 & 18 & $2 . .87$ & 32 & 21.4 & 52 & 65 \\
\hline NCT Delhi & 0.40 & 7 & 0.05 & 4 & 0.34 & 9 & 3.57 & 39 & 9 \\
\hline Odisha & 5.25 & 22 & 0.59 & 7 & 4.88 & 19 & 27.79 & 64 & 67 \\
\hline Puducherry & 6.05 & 36 & 0.26 & 3 & 3.98 & 31 & 11.09 & 41 & 35 \\
\hline Punjab & 1.18 & 11 & 0.17 & 5 & 1.68 & 19 & 12.59 & 62 & 24 \\
\hline Rajasthan & 3.08 & 12 & 0.77 & 9 & 3.2 & 15 & 31.39 & 69 & 51 \\
\hline Sikkim & 2.8 & 13 & & 13.5 & 1.74 & 6 & 13.5 & 29 & 38 \\
\hline Tamil Nadu & 6.84 & 36 & & 1 & 6.28 & 9 & 16.37 & 60 & 47 \\
\hline Telangana & 5.23 & 24 & & 5 & 4.62 & 24 & 25.3 & 73 & 38 \\
\hline Tripura & 4.08 & 6 & & 1 & 2.47 & 5 & 12.51 & 36 & 63 \\
\hline Uttar Pradesh & 2.02 & 10 & & 4 & 2.47 & 14 & 20.29 & 55 & 40 \\
\hline Uttarakhand & 5.54 & 13 & & 3 & 4.49 & 12 & 12.88 & 39 & 29 \\
\hline West Bengal & 3.55 & 50 & & 11 & 2.41 & 38 & 25.73 & 70 & 65 \\
\hline
\end{tabular}




\section{Conclusion}

The SECC2011 has provided us for the first time with valuable information on the nature of abject poverty and also on preponderant seven deprivations of rural households in the country. Abject poverty is more among the following type of households; SC/STs, with no literate adults above 25 years, manual casual labour, and those with only one room kucha walls and roof etc.The incidence of abject poverty is more severe as per SECC data when compared with that of more or less similar NFHS findings. On comparing the findings from these two separate studies one can conclude that incidence abject poverty has increased in rural India. Besides, SECC gives deprivations data on five parameters of automatically included and seven deprived categories of households for all the 36 states/UTs, whereas NFHS data has provided nutrition based deprivations of 22 States/UTs. The multi-dimensional poverty estimates of NFHS are on the higher side as compared with SECC data. These two respective multi dimensional poverty figures are much higher than that of NSSO based estimates. The application of differential exclusion criteria can lead to arrival of more or less number of households with deprivations as evidenced by the three approaches presented here and this calls up on the Government of India for the need to coordinate such exercises by different States. The use of temporary identification number (TIN) associated with SECC households and individuals can be used in targeting and monitoring abject and multi dimensional poverty more effectively and in linking these households with NPR and JhandhanAadhaar-Mobile (JAM) enabled better e governance in India.

\section{References}

1. N.C.Saxena Committee Report, (2009) on BPL Census. GoI. Delhi.

2. Radhakrishna, C.Ravi and B.Sambi Reddy (2010), "Can We Really Measure Poverty and Identify the Poor When Poverty Encompasses Multiple Deprivations?".IJHD, Vol.4.No.2, 2010.

3. Report on Socio Economic and Caste Census 2011 by Abhijit Sen Expert Committee on SECC May 2014.

4. Report of the Expert Group to Review the Methodology for Measurement of Poverty, GoI, Planning Commission, June 2014. 